\title{
Review Article \\ Role of Heat-Shock Proteins in Cellular Function and in the Biology of Fungi
}

\author{
Shraddha Tiwari, Raman Thakur, and Jata Shankar \\ Department of Biotechnology and Bioinformatics, Jaypee University of Information Technology, Solan, Himachal Pradesh 173234, India \\ Correspondence should be addressed to Jata Shankar; jata.shankar@juit.ac.in
}

Received 30 September 2015; Revised 20 November 2015; Accepted 16 December 2015

Academic Editor: Maxim Golovkin

Copyright ( 2015 Shraddha Tiwari et al. This is an open access article distributed under the Creative Commons Attribution License, which permits unrestricted use, distribution, and reproduction in any medium, provided the original work is properly cited.

\begin{abstract}
Stress (biotic or abiotic) is an unfavourable condition for an organism including fungus. To overcome stress, organism expresses heat-shock proteins (Hsps) or chaperons to perform biological function. Hsps are involved in various routine biological processes such as transcription, translation and posttranslational modifications, protein folding, and aggregation and disaggregation of proteins. Thus, it is important to understand holistic role of Hsps in response to stress and other biological conditions in fungi. Hsp104, Hsp70, and Hsp40 are found predominant in replication and Hsp90 is found in transcriptional and posttranscriptional process. Hsp90 and Hsp70 in combination or alone play a major role in morphogenesis and dimorphism. Heat stress in fungi expresses Hsp60, Hsp90, Hsp104, Hsp30, and Hsp10 proteins, whereas expression of Hsp12 protein was observed in response to cold stress. Hsp30, Hsp70, and Hsp90 proteins showed expression in response to $\mathrm{pH}$ stress. Osmotic stress is controlled by small heat-shock proteins and Hsp60. Expression of Hsp104 is observed under high pressure conditions. Out of these heat-shock proteins, Hsp90 has been predicted as a potential antifungal target due to its role in morphogenesis. Thus, current review focuses on role of Hsps in fungi during morphogenesis and various stress conditions (temperature, $\mathrm{pH}$, and osmotic pressure) and in antifungal drug tolerance.
\end{abstract}

\section{Introduction}

Kingdom Fungi encompass a diverse taxonomy involving filamentous and nonfilamentous fungus, which can be classified on the basis of diversity, morphology, growth and development, reproduction, evolution, ability of causing infection, and toxigenicity $[1,2]$. Throughout the evolution, fungi have developed diverse mode of reproduction and ability to adapt to their environment [3]. Mode of feeding is absorption in fungi, for which they adhere or grow within the substrate in the form of hyphae. During adverse conditions, filamentous growth takes place to allow easier nutrient diffusion by providing large surface area of hyphae. Generally, fungi require warm and humid conditions for growth. Decrease in temperature causes fungal dormancy (spores are resistant to cold), while increasing temperature leads to degradation of fungi [1]. Thus, temperature initiates stress responses in fungi, which can be either heat-shock or cold-shock affecting the life cycle and cellular processes. Optimum temperature for growth of various fungi (Histoplasma capsulatum, Aspergillus fumigatus, and Cryptococcus neoformans) is around $37^{\circ} \mathrm{C}[4$, 5]. Increase in temperature generally causes attenuation and ultimately leads to death of the organism $[6,7]$. Fungus such as Saccharomyces cerevisiae can grow at higher temperature $\left(41^{\circ} \mathrm{C}\right)$ [8]. In dimorphic fungi (H. capsulatum), morphology and temperature are linked with each other which converts from filamentous to yeast form at elevated temperature and vice versa [9].

Stress is a critical factor and plays a key role in functional characteristics of fungi. Protein denaturation has been reported in stress and during modulation in temperature, which causes native misfolding of protein and protein aggregation ultimately leading to the loss of biological functions and also leads to cell apoptosis [10]. The stress related changes are responded by a set of proteins, which facilitate survival of the organism. The family of these proteins is termed as Hsps. Hsps are found ubiquitously in a cell (cytosol, mitochondria, endoplasmic reticulum, nucleus, and cell membrane) [11]. 


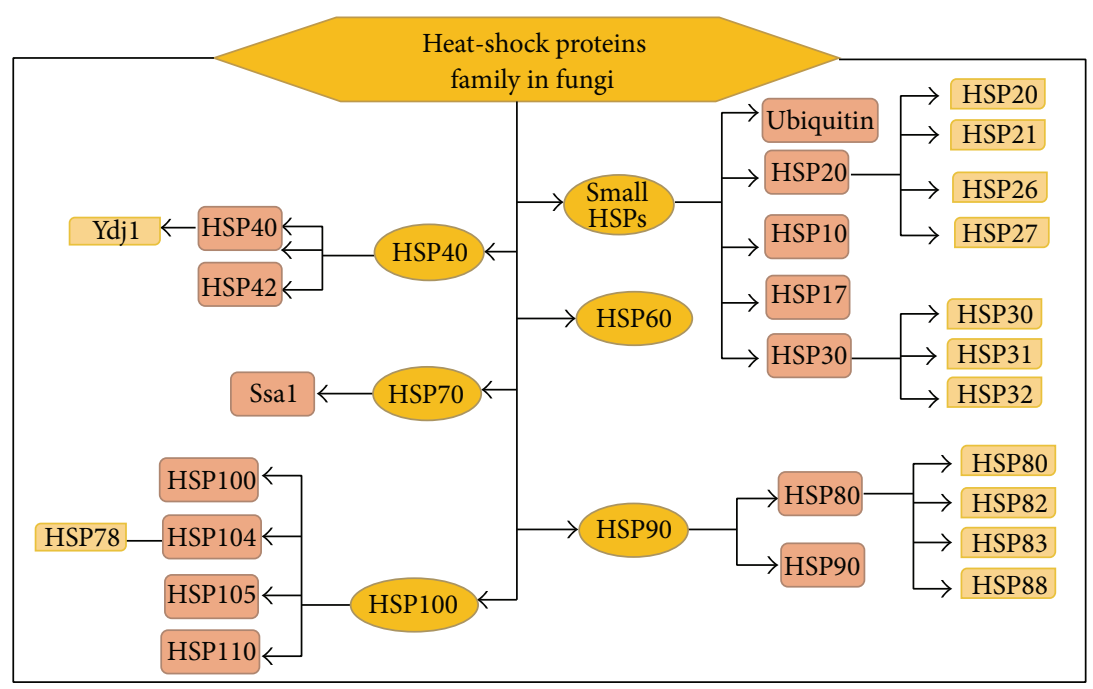

FIGURE 1: Heat-shock proteins family in fungi categorised on the basis of molecular mass and functional role. Subfamily and classes are derived from previous reviews [20, 23-26].

Major role of Hsps involves the cell cycle progression, replication, and transcriptional and posttranslational processes such as protein folding, stability, transportation, and degradation and they are also reported in the activation of many key signal transducers in fungi $[11,12]$. Hsps are highly conserved biomolecules which are constitutively expressed and upregulated in response to various stress conditions (biotic and abiotic) [13]. It is also suggested that Hsp plays an important role in homeostasis stress response.

In protein related disorders, Hsps act as disease suppressor by acting as catalytic polypeptide unfolding isomerase and refolding the mismatched or aggregated proteins [14]. Hsps are categorised on the basis of their molecular weight. Hsps are involved in many regulatory pathways and behave as molecular chaperons for other cellular proteins [11]. The Hsps range in molecular weight from 15 to $110 \mathrm{kDa}$ and are divided into groups based on both size and function [11, 15]. Hsps are divided into several families based on their molecular mass: $100,90,70$, and $60 \mathrm{kDa}[16]$. Also, with low molecular mass of $12-43 \mathrm{kDa}$ they are known as small Hsps. Small Hsps contain 80-100 amino acids conserved site at the Cterminus and a $\alpha / \beta$-crystalline domain [17]. In addition, it is believed that there exists another class of low-molecularweight Hsp, ubiquitin $(8 \mathrm{kDa})$, characteristic of eukaryotic organisms [18]. Hsps are classified based on their functions: chaperones (Hsps 70 and 60), proteins with catalytic activity (proteases, Hsp100, ubiquitin, and tyrosine phosphatase), and proteins with an obscure function ( $\alpha$-crystalline and secreted glycoproteins) [19]. Different Hsps in fungi on the basis of their molecular weight, cellular localization, and functional characterization are illustrated in Table 1 and fungal Hsps families are presented in Figure 1. Hsps are induced by two mechanisms in fungi, specific mechanism and general mechanism. The former is induced by temperature stress and the latter by other stresses such as $\mathrm{pH}$, oxidative stress, osmotic stress, starvation, or antifungal stress [20]. Thus, we reviewed the role of different Hsps involved in fungal biology and their role in both optimal growth conditions and stress responses. Studies have shown that the predominant Hsps of fungal kingdom are Hsp90, Hsp70, and Hsp20-40, which play crucial role in morphogenetic changes, stress adaptation, and antifungal resistance $[21,22]$.

This review summarizes the role of Hsps involved in functional characteristics of fungi (S. cerevisiae, C. albicans, $P$. brasiliensis, and A. fumigatus) that includes morphogenesis (conidiation and dimorphism) and various stress responses such as heat stress, $\mathrm{pH}$ (acidity/basicity), osmolarity, and antifungal tolerance studies of fungi.

\section{Role of Hsp90 and Hsp70 in Fungal Morphogenesis}

Generally asexual reproduction of fungi involves four different stages starting with dormant conidia which convert into vegetative hyphae after few hours and grow to form a network of hyphae called mycelia. Mycelium leads to the formation of aerial hyphae which produces conidia [27]. The Hsps participate in the morphogenesis of fungi and play a major role in the replication, transcription, posttranscriptional process, translation, posttranslational processes, and the activation of signalling pathways. In yeasts (S. cerevisiae and C. albicans), Hsp104 in association with Hsp40 and Hsp70 helps in reactivation and aggregation of denatured protein, by providing disaggregated protein to Hsp40 and Hsp70 as a substrate [28, 29]. In addition to these functions, Hspl04 is also involved in replication of yeast prions, for example, PIN1 and URE3 [30]. Expression of Hsp104 and Hsp70 is regulated by HspHsf (heat-shock factor) interaction which can be stimulated by heat stress in yeast [31]. Cdc37p, cochaperon of Hsp90 in S. cerevisiae, is involved in implication of protein kinase $\mathrm{C}$ and glycerol pathway and is regulated by various phosphorylation sites present in it [32]. Hsp90 is an essential component of cytoplasmic Hsp90-Hsp70 chaperone network responsible 
TABLE 1: Description of heat-shock protein in fungi based on molecular weight, cellular location, and their functions.

\begin{tabular}{|c|c|c|c|c|}
\hline Hsps & $\begin{array}{c}\text { Molecular } \\
\text { weight }(\mathrm{kDa})\end{array}$ & $\begin{array}{l}\text { Cellular } \\
\text { location }\end{array}$ & Cellular functions & References \\
\hline Hsp8.5 & 8 & CyP & Ubiquitination & {$[57,58]$} \\
\hline Hsp10 & 10 & M & $\begin{array}{l}\text { Stabilize catalytic subunit of DNA } \\
\text { polymerase- } \alpha \text { and protein folding in } \\
\text { mitochondria }\end{array}$ & {$[59,60]$} \\
\hline Hsp12 & $10-20$ & $\begin{array}{l}\text { CyP, CW, } \\
\text { PM }\end{array}$ & $\begin{array}{l}\text { Stress tolerance, maintaining cell } \\
\text { morphology, cell adhesion, and } \\
\text { germ tube formation }\end{array}$ & {$[49,61]$} \\
\hline Hsp17 & $10-20$ & $\mathrm{M}$ & Membrane lipid bilayer stabilizer & {$[57]$} \\
\hline Hsp21 & $20-30$ & CW, ER & $\begin{array}{l}\text { Fungal adaptation in environmental } \\
\text { stress and pathogenicity, glycerol } \\
\text { and glycogen regulation, virulence } \\
\text { factor in eukaryotic pathogens, and } \\
\text { hyphal formation }\end{array}$ & {$[62,63]$} \\
\hline Hsp26 & $20-30$ & $\mathrm{CyP}$ & Induced in low $\mathrm{pH}$ conditions & {$[28,64]$} \\
\hline Hsp27 & $20-30$ & $\mathrm{~N}, \mathrm{CyP}$ & Cytoskeleton & {$[57]$} \\
\hline Hsp30 & 30 & $\mathrm{PM}$ & $\begin{array}{l}\text { Regulates membrane function } \\
\text { under heat shock conditions, } \\
\text { negatively regulates } \mathrm{H}^{+} \text {ATPase }\end{array}$ & {$[40]$} \\
\hline Hsp31 & 30 & ER & $\begin{array}{l}\text { Growth under partial pressure } \\
\text { conditions and act as molecular } \\
\text { chaperone }\end{array}$ & {$[65]$} \\
\hline Hsp32 & 30 & CyP & Heme-oxygenase & {$[57,63]$} \\
\hline Hsp40 & 40 & $\begin{array}{l}\text { CyS, M, } \\
\text { ER }\end{array}$ & $\begin{array}{l}\text { Cell physiology and cofactor of } \\
\text { Hsp70 }\end{array}$ & {$[66,67]$} \\
\hline Hsp42 & 40 & CyS & $\begin{array}{l}\text { Suppress the aggregation of } \\
\text { nonnative protein }\end{array}$ & {$[68]$} \\
\hline Hsp60 & 60 & $\mathrm{M}, \mathrm{CyS}$ & $\begin{array}{l}\text { Immunological properties, } \\
\text { upregulated in biotic and abiotic } \\
\text { stress }\end{array}$ & {$[69-71]$} \\
\hline Hsp70 & 68 & $\begin{array}{c}\text { CyS, N, } \\
\text { ER, R, M }\end{array}$ & $\begin{array}{l}\text { Initial folding of nascent } \\
\text { polypeptide and ATPase activity }\end{array}$ & {$[34,72,73]$} \\
\hline Hsp78 & 70 & $\mathrm{M}$ & $\begin{array}{l}\text { Mitochondrial thermotolerance and } \\
\text { pressure tolerance }\end{array}$ & {$[73]$} \\
\hline Hsp80 & 80 & СуP & $\begin{array}{l}\text { Interact with unfolded polypeptide } \\
\text { individually or in complex }\end{array}$ & {$[73]$} \\
\hline Hsp82 & 80 & СyP & $\begin{array}{l}\text { Pheromone signalling and negative } \\
\text { regulation of Hsf1 }\end{array}$ & {$[73,74]$} \\
\hline Hsp83 & 83 & CyS & $\begin{array}{l}\text { Interaction with nascent chain } \\
\text { polypeptide and signal transduction }\end{array}$ & {$[24]$} \\
\hline Hsp88 & 88 & CyS & Interact with Hsp30 & {$[75,76]$} \\
\hline Hsp90 & 90 & CyS, ER, N & $\begin{array}{l}\text { Folding and maintenance of client } \\
\text { proteins, involved in transcriptional } \\
\text { and posttranscriptional processes } \\
\text { and activation of signal transducers }\end{array}$ & {$[72,77]$} \\
\hline Hsp100 & 100 & CyS & $\begin{array}{l}\text { Catalytic activity and protease with } \\
\text { ATPase activity }\end{array}$ & {$[20]$} \\
\hline Hsp104 & 100 & CyS & $\begin{array}{l}\text { Thermotolerance, survival at } \\
\text { stationary phase, ethanol tolerance, } \\
\text { reactivate denatured and aggregated } \\
\text { proteins, and replication of yeast } \\
\text { prions }\end{array}$ & {$[29,78,79]$} \\
\hline Hsp105 & 105 & $\mathrm{~N}, \mathrm{CyP}$ & Not reported & {$[57,80]$} \\
\hline Hsp110 & 110 & $\mathrm{~N}, \mathrm{CyP}$ & $\begin{array}{l}\text { Misfolding of polypeptide and } \\
\text { hydrolyses of ATP }\end{array}$ & {$[57,81,82]$} \\
\hline
\end{tabular}

CyP: cytoplasm; CyS: cytosol; M: mitochondria; PM: plasma membrane; ER: endoplasmic reticulum; N: nucleus. 
for protein folding. Protein emerging from ribosome is initially folded in nascent polypeptide by $\mathrm{Hsp} 70$ and then passed to the Hsp90 machine which performs later folding [33]. Hsp90 maintains the integrity of client protein which on interaction modulates weak ATPase activity of Hsp90 followed by ATP hydrolysis and remodelling resulting in open form of protein [34]. Hsp70 and Hsp40 are cochaperons of Hsp90, which acts simultaneously. Hsp70 requires adapter protein (Stil/Hopl) to associate with Hsp90 by inhibiting ATPase activity of Hsp90 which is before activated by Ahal (Hsp90 cochaperone) ultimately causing polypeptide release [35]. Tahl/Pihl (chromatin remodelling) and Sgt1 (contributes to kinetochore assembly) are the cochaperons of Hsp90 in S. cerevisiae. Tah1/Pihl is involved in regulation of Hsp90 chaperone complex by inhibiting Hsp90 ATPase activity whereas Sgtl has no effect on ATPase activity [36]. The other cochaperon Cdc37 with Hsp90 modulates function of crucial cell cycle regulator, Cdc28, Cdc50, Cdc60, and Swe1 [37]. Acetylation of K270 residue is important for Hsp90 function in S. cerevisiae [38]. S. cerevisiae is known to have three small Hsps, that is, Hsp30, Hsp26, and Hsp12. Hsp30 is involved in energy conservation by inhibiting ATPase during stress conditions [20]. Mutation in Hsp70 leads to expression of $h s p$ genes at temperatures that are optimal for growth of the organisms [39]. Msn2 and Msn4 $(140 \mathrm{kDa})$ are the regulatory proteins which are involved in the activation and expression of $h s p 12$ by recognising stress response elements with characteristic nucleotide sequence "CCCCT" [20]. Regulatory factors of S. cerevisiae, Yap1, and Yap2 account for the regulation of Hsp30 [40]. For the promoters of $h s p 70$ and hsp12 genes, GTPase of Ras family and cAMP act as negative control [41]. Transcription and posttranscription processes involve regulation of $h s p 90$, regulated by Hsf1 in S. cerevisiae $[42,43]$. Hsf1 (heat-shock transcription factor) is activated by hyper phosphorylation in response to heat-shock via heat-shock element that leads to increased transcription and accumulation of heat-shock gene products (Hsp60, Hsp70, Hsp78, Hsp90, and Hsp104) [42, 44]. Hsp70 interacts with Hsfl encoding protein required for the function of Hsp90 involved in the repression of Hsfl by feedback inhibition mechanism $[45,46]$. MAPK (Slt2) acts as a client protein for Hsp90 which activates Rlm1 (transcriptional factor) involved in maintenance of cell integrity [47, 48]. Hsp12 maintains normal cell morphology that is essential for survival and growth [49].

In C. albicans morphogenesis is profoundly influenced by temperature and negatively regulated by $\mathrm{Hsp} 90$ by repressing Ras/PKA pathway, which is a positive regulator of morphogenesis in C. albicans. Thus, Hsp90 in C. albicans functions as a morphological controller [50]. At low temperature $\left(11-15^{\circ} \mathrm{C}\right)$ Ras/PKA pathway is repressed by activation of $\mathrm{Hsp} 90$ which relieves Ras/PKA pathway at elevated temperature $\left(37^{\circ} \mathrm{C}\right)$ resulting in filamentation [51, 52]. Hsp12 protein in cell wall is induced during stationary growth phase of morphogenesis and has a facilitating role in hyphal formation [53]. Hsp90 regulates Slt2 (stress-activated, mitogen-activated protein kinase) and $\mathrm{Mkcl}$ (calcineurin), which are involved in maintaining cell integrity via MAPK pathway [54]. Other factors such as drugs and human steroid hormones influence the morphogenesis of $C$. albicans $[55,56]$.

Hsp90 protein has been studied in filamentous fungus A. fumigatus by Lamoth et al. [6]. Repression of $h s p 90$ gene showed decreased spore viability, decreased hyphal growth, and severe defects in germination and conidiation. Downregulation of the conidiation-specific transcription factors BrlA, WetA, and AbaA was reported [6]. Under heat stress, Hsp90 protein moves from cytosol to nucleus and carries nuclear localization signal suggesting that it might have role in transcriptional regulation during heat stress [6]. Thus, it suggests that Hsp90 holds a key role in morphogenesis of $A$. fumigatus.

2.1. Conidiation. Conidia are produced by asexual sporulation in filamentous fungi. They are generally produced after mycelial stage in vegetative growth [83]. In Aspergillus species (Aspergillus nidulans and A. fumigatus) conidiation is controlled by Hsp90-calcineurin pathway; deletion of calcineurin resulted in impaired hyphal growth, decrease in $\beta$-glucan content of cell wall, and defective sporulation. Downregulation of transcriptional factor (BrlA, WetA, and FlbA) in A. nidulans and (BrlA, FlbA, and AbaA) in A. fumigatus has been reported during inhibition of Hsp90calcineurin pathway $[6,84,85]$. Hsp90 is widely distributed in cytosol under standard growth and moves to organs according to stress conditions such as in nucleus under heat stress and in cell wall or hyphal tips under cell wall stress [6]. Induction of Hsp90 has been shown to be essential during caspofungin drug treatment in A. fumigatus [86]. Reverse internal acetylation has been reported in A. fumigatus Hsp90, which is an important regulatory mechanism of Hsp90 [21].

Transcription factor (Hsfl) in C. albicans is temporarily activated during thermal stress (e.g., $\left.37^{\circ} \mathrm{C}\right)$ [42]. The function of transcription factor, Hsfl, is repressed by $\mathrm{Hsp} 90$ which involves client proteins secretion, vesicular transport, and mitochondrial membrane components [87]. In dormant conidial stage of yeast (N. crassa, C. albicans, and S. cerevisiae), Hsp30-Hsp80 complex with Hsp70 interacts with unfolded polypeptide (homologous with Hsp90) [88, 89]. From the previous studies it has been shown that $h s p 70$ transcripts in N. crassa are predominant at aerial and dormant conidia stage which fluctuate on further progressive stages of germination [90]. The expression of hsp70 transcripts increases during lag and log phase, declined in young aerial hyphae, and is maximum at late aerial hyphae due to transcriptional activation or may be due to decrease in rate of mRNA degradation [91].

2.2. Dimorphism. Dimorphism is the property of fungus in which it converts from one form to another (mycelia to yeast or vice versa) in response to various stress conditions and so plays a key factor in fungal virulence (e.g., P. lutzii, C. albicans, and H. capsulatum) [92]. In normal growth conditions Paracoccidioides exists in mycelial stage and converts in hyphal stage but as the temperature increases $\left(37^{\circ} \mathrm{C}\right)$ it converts into yeast form which is a pathogenic form. 
Paracoccidioides species causes Paracoccidioidomycosis and is endemic to South America. The infection is predominant in male in comparison to female and $17 \beta$-estradiol has been reported to inhibit the transition from mycelia form (infective propagules) to yeast form $[93,94]$. In yeast form of $P$. brasiliensis or $P$. lutzii, hsp70 showed high transcripts [95]. During transition from mycelia to yeast form $h s p 90$ transcript was upregulated at early stage [93]. Thus, Hsps are important in the dimorphism and cell viability of Paracoccidioides $[93,96]$. Calcineurin helps Hsp90 in maintaining environmental changes by regulating dimorphism but not proliferation [97]. The mRNA expression of $h s p 90$ is higher in yeast than mycelial form and gene expression is upregulated during early phase of mycelium to yeast transition. Hsp90 impairs yeast proliferation at $37^{\circ} \mathrm{C}$ but slightly affects mycelial proliferation. The transition from yeast to mycelia form in Paracoccidioides occurs independent of Hsp90 activity. Hsp70 protein is found to be expressed in the yeast phase [23]. Hsp60 is also upregulated in response to thermal stress and involved in differentiation, infection, and colonization [98, 99]. At mycelial stage Calnexin gene, a type of $h s p 60$ gene (cytoplasm), and sbal cochaperon gene were overexpressed whereas in yeast form gene encoding for cochaperons, for example, cprl, $h s p 42, h s p 60, h s p 70$, and $h s p 90$, were upregulated. Thus, it suggested that expression of genes encoding for Hsps is more in yeast form of $P$. brasiliensis [100].

In yeast form of $C$. albicans Hsp90 plays a negative regulatory role in the conversion from yeast to filamentous form which is positively regulated by Ras/PKA pathway [52]. At an elevated temperature $\left(37^{\circ} \mathrm{C}\right)$ filamentation of $C$. albicans occur in serum leading to virulence. Thus, it suggests that repression of $\mathrm{Hsp} 90$ is responsible for inducing yeast to filamentous form. Hsp12p affected by quorum sensing molecule, farnesol, blocks yeast to hyphal transition via cAMP dependent signalling cascade [61]. Surface invasion Ssa (Hsp70) in C. albicans has been reported to be upregulated at hyphal stage [92].

\section{Role of Hsp in Stress Tolerance}

3.1. Temperature. Various problems caused by temperature change are associated with the temperature dependent morphological transitions and protein folding [101]. Heat-shock response is generally seen in the cells affected by thermal stress [12]. In several studies it has been reported that reactive oxygen species (ROS) production is enhanced in cells under thermal stress which also activates Hsps [102]. Temperature stress in dimorphic fungus may have an effect on different phases of life cycle, so protein expression may be phase specific or heat induced [103].

In a model organism $N$. crassa, at temperature $25-37^{\circ} \mathrm{C}$, mycelial form converts to hyphal form with the expression of $70 \mathrm{kDa} H s p$ [104]. As temperature increases (e.g., $45^{\circ} \mathrm{C}$ ), the mycelial form converts to yeast form in N. crassa; the major Hsps of 67,83 , and $98 \mathrm{kDa}$ and minor Hsps of $30 \mathrm{kDa}$ were expressed at germinating conidiophore stage which showed normal growth after one hour [105]. As it has been suggested, upregulated Hsp90 protein and their interaction with calcineurin are responsible for mycelia to yeast transition in $C$ albicans, $S$. cerevisiae, and P. brasiliensis; low level of Hsp90 causes reduction in expression of calcineurin catalytic subunit (CNA2) [97]. As we discussed, in N. crassa, Hsp90 inhibition is responsible for yeast to filamentous transition which is antagonist to Ras/PKA pathway. Thus, it is suggestive that Ras/PKA pathway positively regulates yeast to filament transition and is negatively regulated by Hsp90 [106]. In $A$. fumigatus Hsp90 is involved in initiation of germination and hyphal elongation of dormant conidia [86].

Hsp90 in $P$. brasiliensis prevents cellular and molecular damage of cells in response to heat stress. It plays a role by regulating the level of ROS. At elevated temperature $\left(42^{\circ} \mathrm{C}\right)$ for $4 \mathrm{hr}$, ROS level was found to be increased on inhibition of Hsp90 in yeast cells and showed no effect on ROS level at optimum temperature $\left(37^{\circ} \mathrm{C}\right)$. This study suggested that Hsp90 regulates ROS level only in heat stress [97]. hsp60 has increased level of mRNA expression in heat stress conditions. There is a 5.9-6.9-fold increase in $h s p 60$ mRNA expression that was observed in A. fumigatus and Aspergillus terreus at $40^{\circ} \mathrm{C}$ [13]. In a limited data set of expressed sequence tag analyses of $A$. fumigatus derived at $37^{\circ} \mathrm{C}$ did not observe gene encoding for Hsps [4, 107]. Trichophyton mentagrophyte showed 4.9-fold increased expression of $h s p 60$ when incubated at $40^{\circ} \mathrm{C}$ [13]. C. albicans showed 3.2-fold upregulation at $30^{\circ} \mathrm{C}$. So it can be said that $h s p 60$ induction was highest at $35^{\circ} \mathrm{C}$ to $40^{\circ} \mathrm{C}$, which depends on types of fungus. In Cladosporium cladosporioides no hsp60 transcripts were observed at low optimum temperature $\left(20^{\circ} \mathrm{C}\right)$ for growth [13]. Hsp60 plays an important role in fungal related diseases in humans and acts as an immunological trigger and increase in fungal hsp60 mRNA has been reported $[13,108]$.

At high temperature, Hsp104 protein stabilizes stationary-phase yeast cells and aerobically growing cells of $S$. cerevisiae $[19,109]$. Further, at high temperature, Hsp104 is involved in unfolding of denatured protein with the help of Hsp40 and Hsp70 [29]. Deletion of the hsp104 gene results in the loss of tolerance to not only heat but also the viability of cells stored at low temperatures [20]. On functional basis, Hsp104 showed similarity with Hsp70, which works alternatively in response to thermotolerance [110]. Overexpressed hsp12 also contributes to temperature resistance in S. cerevisiae by accumulating the trehalose [111]. However, in a recent study, it has been shown that trehalose$6 \mathrm{P}$ synthase (Tps1) protein is essential but not trehalose in yeast to maintain the ATP requirement in a heat-shock condition [112].

Hsp30 level also increases at the time of thermotolerance in $S$. cerevisiae. Heat stress results in increase in membrane fluidity which is controlled by increase in amount of Hsp30 in membrane [113]. Heat stress also increases Hsp10 (cochaperone) and Hsp78 (chaperone) in mitochondrial matrix which inhibits Hsp60 ATPase activity resulting in protein folding in S. cerevisiae $[113,114]$.

Hsps also play an important role in response to freezing temperature in S. cerevisiae. Recent studies showed that when yeast cells were stored at $-20^{\circ} \mathrm{C}$, there is an increase in resistance against low temperature [115]. This was due to the expression of Hsp12, which suggested that Hsp12 plays 
a role in freeze tolerance. Sometimes, the role of Hsp12 is interchangeable with trehalose. Hspl2 protein expression is induced at $4^{\circ} \mathrm{C}$ and $0^{\circ} \mathrm{C}$, important for adaptation to cold in S. cerevisiae $[115,116]$. So, Hspl2 plays an important role in cryopreservation to maintain viability of cells. Hsp12 shows similarity with trehalose activity in maintaining membrane integrity against desiccation [117]. Hsp12 functions at plasma membrane level to maintain cells integrity in freezing stage in S. cerevisiae [111].

3.2. $p H$. $\mathrm{pH}$ plays important role in $h s p$ gene expression which involves $\mathrm{PacC} / \mathrm{PalA}$ pathway. The PalA protein is a member of conserved signalling cascade and is involved in $\mathrm{pH}$ mediated regulation of gene expression in A. nidulans. $\mathrm{PacC}$ is a regulator which is required for activation/repression of acid/alkaline associated gene in filamentous fungi [118, 119]. The PalA protein mediates the proteolytic activation of PacC [120]. Freitas et al. showed that at optimum temperature and acidic $\mathrm{pH}, h s p 30, h s p 70$, and $h s p 90$ genes are induced depending upon the extracellular $\mathrm{pH}$ conditions. In mycelial culture of A. nidulans at $\mathrm{pH}$ 5.0, transcript level of $h s p 30$, $h s p 70$, and $h s p 90$ is preferentially high. At alkaline $\mathrm{pH}$, in the presence of PalA environment, there is a decrease in $h s p 30$ transcripts that has been observed. $h s p 70$ transcripts were observed to be high at $\mathrm{pH} 8$ in PalA environment. Also, change of $\mathrm{pH}$ (alkaline or acidic) does not influence the transcription of $h s p 90$ in A. nidulans [118]. Generally, oxidative and osmotic stresses and heat-shock cause an increase in transient transcription rate in yeast in comparison to high alkaline $\mathrm{pH}$ stress [121].

3.3. Osmotic Pressure. Osmotic pressure is responsible for causing membrane destabilization by increasing membrane fluidity which is overcome by induction of Hsp12 and Hsp26 [122]. $h s p 12$ and $h s p 26$ genes are generally regulated by Msn2/Msn4p (Trans-activators), which helps in activation under pressure stress [123]. Small Hsp26p has molecular chaperone activity help membrane from irreversible aggregation of proteins [69]. Hsp30, a plasma membrane protein, is also found upregulated in yeast cells under pressure related stress conditions but independent of Msn2/Msn4p [40]. Hsp30 works by downregulating the activity of $\mathrm{H}^{+}$ATPase on ATP depletion and so plays a role in energy conservation $[113,124]$. Hsp31 acts as a molecular chaperone in response to pressure stress. It is generally present in endoplasmic reticulum and plays partial role in growth and catalysis of misfolded proteins at $25 \mathrm{MPa}$ [113]. The loss of mitochondrial function due to pressure stress is overcome by upregulation of Hsp60 and Hsp78 [125]. At high pressure conditions (150$180 \mathrm{MPa}$ ), induction of Hsp104 takes place, leads to unfolding of denatured proteins, and increases viability of cells [126, 127].

\section{Heat-Shock Protein as Antifungal Targets}

Toxicity always remained a serious concern and a drug target is an emerging area. In current scenario to overcome various fungal related diseases in both plants and animals, research is being focused on the development of various therapeutic targets. One such interesting area to focus on is Hsps, due to its very wide role in fungal survival during stress conditions. In recent years, Hsp 90 has been proposed as antifungal target. Hsp90 inhibitors geldanamycin and their derivatives showed antifungal activity and synergistic effect with caspofungin against $A$. fumigatus and C. albicans $[86,128,129]$.

In $P$. lutzii, $P$. brasiliensis morphological transitions (mycelia to yeast) are important for causing disease, which involves the role of Hsp90, as Hsp90 strengthens stress response in these fungi [97]. When these Paracoccidioides species were treated with benzoquinone ansamycin antibiotic and geldanamycin (inhibitor of Hsp90), inhibition from mycelial to yeast transition was observed and causes the diminishing of yeast form. Hsps have also important role in drug resistance. Hsp90 is involved in resisting fungi with the effect of azoles. In recent studies it has been seen that when fungi (C. albicans, S. cerevisiae, and A. fumigatus) have impairment or scarcity of Hsp90 then they are prone to antifungal drug, fluconazole (Azole family), while in the presence of Hsp90 they showed resistance to fluconazole effect. Hsp90 develops the resistance property which involves calcineurin pathway [130]. Activation of Hsp90-calcineurin complex leads to drug resistance (Geldanamycin) and various stress responses. Complete inhibition of $\mathrm{Hsp} 90$ is difficult as it is highly expressed in basal conditions and highly conserved [86]. Hsp70 have been found to modulate the effect of caspofungin via Hsp90-Hop/Stil (cochaperons) in A. fumigatus. Hsp70 have Stil binding region which on activation responds to thermal stress and caspofungin effect. Hsp104 have ATPase activity and play an important role in stress response via activating Hsp70 and so help in protein refolding of aggregated proteins. Being involved in such important function, Hsp104 also emerged as important antifungal target. However, in a genome wide gene expression study of A. fumigatus in response to amphotericin B showed downregulation of $h s p 88$ transcripts [131]. Studies on S. cerevisiae showed that treatment of small amount of Guanidinium hydrochloride with yeast inhibits the activity of $\mathrm{Hsp10} 4$ by binding the $\mathrm{M}$-domain of Hsp104, hence inhibiting the Hsp104-Hsp70 interaction, causing the inhibition of stress tolerance of yeast [132].

Due to unavailability of commercial fungal vaccines for humans, it is a matter of great significance to develop vaccines against fungal infections. This is the issue of challenge in both scientific and technological aspect because of the lack of understanding of immune response against fungal antigens. Recent studies showed that heat killed yeast can be used as vaccine against five different fungal infections. Antigen having the same antigenic epitope in different fungi is potentially recognised by the same antibodies against them, which could inhibit fungal growth and development [133]. Various Hsps such as Hsp70, Hsp40, Hsp90, and Hsp60 has been shown to be upregulated when different sets of fungi (C. albicans, P. brasiliensis, and Coccidioides posadasii) were injected in mice model [134]. Hsps come under conserved protein domain common in fungi which commonly act as an antigen in fungal infections and showed potential for the development of pan fungal vaccine, providing absence of antigenic region of fungal Hsps in human counterpart. 


\section{Conclusion}

Heat-shock proteins are expressed during various stress conditions. Expression of Hsps may be specific to different conditions, for example, temperature, osmotic pressure, $\mathrm{pH}$, antifungals, and oxidative stress. Hsp90 and Hsp70 are the predominant Hsps found in the morphogenesis of fungi. They work individually or in Hsp90-Hsp70 complex in different fungi and play an important role in nascent folding of aggregated polypeptide, hence providing stability. Hsp40 and Hsp104 are also found to be upregulated during morphogenesis of fungi. In dimorphism expression of various Hsps (Hsp90, Hsp70, Hsp60, and Hsp40) is unregulated in the yeast stage. So we can conclude that in yeast form expression of Hsp is higher than mycelial stage and involves Ras/PKA pathway. Heat stress induces the expression of various Hsps (Hsp90 and Hsp60), whereas Hsp12 is found to be upregulated in freeze tolerance of fungi. Fungus activates PacC/PalA pathway to withstand $\mathrm{pH}$ stress. In the presence of palA gene, Hsp30, Hsp70, and Hsp90 are predominantly upregulated in acidic $\mathrm{pH}$, but level of Hsp30 decreases in alkaline $\mathrm{pH}$. Osmotic stress response is overcome by upregulating Hsp12 and Hsp26 in membrane, Hsp78 and Hsp60 in mitochondria, Hsp30 in plasma membrane, and Hsp31 in endoplasmic reticulum. Hsp104 is expressed at high hydrostatic pressure. Hsp70, Hsp90, and Hsp104 are found to be expressed in response to various antifungal compounds, so these Hsps can be studied further as antifungal targets. Thus further study of fungal Hsps at mRNA level and protein level needs to be investigated to understand the biology of organism and to develop potent antifungal targets to overcome fungal related losses.

\section{Conflict of Interests}

The authors declare that there is no conflict of interests regarding the publication of this review article.

\section{Acknowledgment}

The authors are thankful to Department of Biotechnology and Bioinformatics, Jaypee University of Information Technology (Solan), Himachal Pradesh, India, for financial support to Ph.D. students Shraddha Tiwari and Raman Thakur.

\section{References}

[1] M. Papagianni, "Fungal morphology and metabolite production in submerged mycelial processes," Biotechnology Advances, vol. 22, no. 3, pp. 189-259, 2004.

[2] J. Shankar, "An overview of toxins in Aspergillus associated with pathogenesis," International Journal of Life Sciences Biotechnology and Pharma Research, vol. 2, no. 2, pp. 16-31, 2013.

[3] F. Lamoth, P. R. Juvvadi, and W. J. Steinbach, "Heat shock protein 90 (Hsp90) in fungal growth and pathogenesis," Current Fungal Infection Reports, vol. 8, no. 4, pp. 296-301, 2014.

[4] J. Shankar, S. Nigam, S. Saxena, T. Madan, and P. U. Sarma, "Identification and assignment of function to the genes of
Aspergillus fumigatus expressed at $37^{\circ} \mathrm{C}$," Journal of Eukaryotic Microbiology, vol. 51, no. 4, pp. 428-432, 2004.

[5] B. Klinkert and F. Narberhaus, "Microbial thermosensors," Cellular and Molecular Life Sciences, vol. 66, no. 16, pp. 2661-2676, 2009.

[6] F. Lamoth, P. R. Juvvadi, J. R. Fortwendel, and W. J. Steinbach, "Heat shock protein 90 is required for conidiation and cell wall integrity in Aspergillus fumigatus," Eukaryotic Cell, vol. 11, no. 11, pp. 1324-1332, 2012.

[7] R. Bhabhra and D. S. Askew, "Thermotolerance and virulence of Aspergillus fumigatus: role of the fungal nucleolus," Medical Mycology, vol. 43, supplement 1, pp. S87-S93, 2005.

[8] M. D. Leach and L. E. Cowen, "Surviving the heat of the moment: a fungal pathogens perspective," PLoS Pathogens, vol. 9, no. 3, Article ID e1003163, 2013.

[9] B. Maresca and G. S. Kobayashi, "Dimorphism in Histoplasma capsulatum: a model for the study of cell differentiation in pathogenic fungi," Microbiological Reviews, vol. 53, no. 2, pp. 186-209, 1989.

[10] S. K. Sharma, P. Christen, and P. Goloubinoff, "Disaggregating chaperones: an unfolding story," Current Protein and Peptide Science, vol. 10, no. 5, pp. 432-446, 2009.

[11] K. C. Kregel, "Invited review: heat shock proteins: modifying factors in physiological stress responses and acquired thermotolerance," Journal of Applied Physiology, vol. 92, no. 5, pp. 21772186, 2002.

[12] J. Verghese, J. Abrams, Y. Wang, and K. A. Morano, "Biology of the heat shock response and protein chaperones: budding yeast (Saccharomyces cerevisiae) as a model system," Microbiology and Molecular Biology Reviews, vol. 76, no. 2, pp. 115-158, 2012.

[13] R. B. Raggam, H. J. F. Salzer, E. Marth, B. Heiling, A. H. Paulitsch, and W. Buzina, "Molecular detection and characterisation of fungal heat shock protein 60," Mycoses, vol. 54, no. 5, pp. e394-e399, 2011.

[14] S. Priya, S. K. Sharma, and P. Goloubinoff, "Molecular chaperones as enzymes that catalytically unfold misfolded polypeptides," FEBS Letters, vol. 587, no. 13, pp. 1981-1987, 2013.

[15] M. J. Schlesinger, "Heat shock proteins," The Journal of Biological Chemistry, vol. 265, no. 21, pp. 12111-12114, 1990.

[16] W. H. Mager and A. J. J. De Kruijff, "Stress-induced transcriptional activation," Microbiological Reviews, vol. 59, no. 3, pp. 506-531, 1995.

[17] N. B. Gusev, N. V. Bogatcheva, and S. B. Marston, "Structure and properties of small heat shock proteins (sHsp) and their interaction with cytoskeleton proteins," Biochemistry, vol. 67, no. 5, pp. 511-519, 2002.

[18] M. J. Schlesinger, "Heat shock proteins: the search for functions," Journal of Cell Biology, vol. 103, no. 2, pp. 321-325, 1986.

[19] N. Plesofsky-Vig, "The heat shock proteins and the stress response," in Biochemistry and Molecular Biology, vol. 3 of The Mycota, pp. 171-190, Springer, Berlin, Germany, 1996.

[20] V. M. Tereshina, "Thermotolerance in fungi: the role of heat shock proteins and trehalose," Microbiology, vol. 74, no. 3, pp. 247-257, 2005.

[21] F. Lamoth, P. R. Juvvadi, and W. J. Steinbach, "Histone deacetylase inhibition as an alternative strategy against invasive aspergillosis," Frontiers in Microbiology, vol. 6, article 96, 2015.

[22] V. M. Tereshina, "Thermotolerance in fungi: the role of heat shock proteins and trehalose," Mikrobiologiya, vol. 74, no. 3, pp. 293-304, 2005. 
[23] S. P. Da Silva, M. S. S. Felipe, M. Pereira, M. O. Azevedo, and C. M. D. A. Soares, "Phase transition and stage-specific protein synthesis in the dimorphic fungus Paracoccidioides brasiliensis," Experimental Mycology, vol. 18, no. 4, pp. 294-299, 1994.

[24] C. Jolly and R. I. Morimoto, "Role of the heat shock response and molecular chaperones in oncogenesis and cell death," Journal of the National Cancer Institute, vol. 92, no. 19, pp. 1564$1572,2000$.

[25] R. Matthews, B. Maresca, J. Burnie et al., "Stress proteins in fungal diseases," Medical Mycology, vol. 36, pp. 45-51, 1997.

[26] H. H. Kampinga, J. Hageman, M. J. Vos et al., "Guidelines for the nomenclature of the human heat shock proteins," Cell Stress and Chaperones, vol. 14, no. 1, pp. 105-111, 2009.

[27] L. Wang and X. Lin, "Morphogenesis in fungal pathogenicity: shape, size, and surface," PLoS Pathogens, vol. 8, no. 12, Article ID e1003027, 2012.

[28] M. Amorós and F. Estruch, "Hsflp and Msn2/4p cooperate in the expression of Saccharomyces cerevisiae genes HSP26 and HSP104 in a gene- and stress type-dependent manner," Molecular Microbiology, vol. 39, no. 6, pp. 1523-1532, 2001.

[29] J. R. Glover and S. Lindquist, "Hsp104, Hsp70, and Hsp40: a novel chaperone system that rescues previously aggregated proteins," Cell, vol. 94, no. 1, pp. 73-82, 1998.

[30] R. D. Wegrzyn, K. Bapat, G. P. Newnam, A. D. Zink, and Y. O. Chernoff, "Mechanism of prion loss after Hsp104 inactivation in yeast," Molecular and Cellular Biology, vol. 21, no. 14, pp. 46564669, 2001.

[31] H. Zähringer, M. Burgert, H. Holzer, and S. Nwaka, "Neutral trehalase Nthlp of Saccharomyces cerevisiae encoded by the NTH1 gene is a multiple stress responsive protein," FEBS Letters, vol. 412, no. 3, pp. 615-620, 1997.

[32] P. Hawle, D. Horst, J. P. Bebelman, X. X. Yang, M. Siderius, and S. M. van der Vies, "Cdc37p is required for stress-induced highosmolarity glycerol and protein kinase $\mathrm{C}$ mitogen-activated protein kinase pathway functionality by interaction with Hoglp and Slt2p (Mpklp)," Eukaryotic Cell, vol. 6, no. 3, pp. 521-532, 2007.

[33] M. Patricia Hernández, W. P. Sullivan, and D. O. Toft, “The assembly and intermolecular properties of the hsp70-Hophsp90 molecular chaperone complex," The Journal of Biological Chemistry, vol. 277, no. 41, pp. 38294-38304, 2002.

[34] M. Taipale, D. F. Jarosz, and S. Lindquist, "HSP90 at the hub of protein homeostasis: emerging mechanistic insights," Nature Reviews Molecular Cell Biology, vol. 11, no. 7, pp. 515-528, 2010.

[35] K. Richter, P. Muschler, O. Hainzl, J. Reinstein, and J. Buchner, "Stil is a non-competitive inhibitor of the Hsp90 ATPase. Binding prevents the N-terminal dimerization reaction during the ATPase cycle," The Journal of Biological Chemistry, vol. 278, no. 12, pp. 10328-10333, 2003.

[36] K. Eckert, J.-M. Saliou, L. Monlezun et al., "The Pih1-Tah1 cochaperone complex inhibits Hsp90 molecular chaperone ATPase activity," The Journal of Biological Chemistry, vol. 285, no. 41, pp. 31304-31312, 2010.

[37] M. Mollapour, S. Tsutsumi, A. C. Donnelly et al., "Swe1Wee1dependent tyrosine phosphorylation of $\mathrm{Hsp} 90$ regulates distinct facets of chaperone function," Molecular Cell, vol. 37, no. 3, pp. 333-343, 2010.

[38] B. T. Scroggins, K. Robzyk, D. Wang et al., "An acetylation site in the middle domain of Hsp90 regulates chaperone function," Molecular Cell, vol. 25, no. 1, pp. 151-159, 2007.
[39] M. Hideyuki, K. Takayoshi, T. Hozumi, H. Dai, M. Tokichi, and T. Chikako, "Isolation and characterization of SSE1 and SSE2, new members of the yeast HSP70 multigene family," Gene, vol. 132, no. 1, pp. 57-66, 1993.

[40] I. J. Seymour and P. W. Piper, "Stress induction of HSP30, the plasma membrane heat shock protein gene of Saccharomyces cerevisiae, appears not to use known stress-regulated transcription factors," Microbiology, vol. 145, no. 1, pp. 231-239, 1999.

[41] F. Estruch, "Stress-controlled transcription factors, stressinduced genes and stress tolerance in budding yeast," FEMS Microbiology Reviews, vol. 24, no. 4, pp. 469-486, 2000.

[42] S. Nicholls, M. D. Leach, C. L. Priest, and A. J. P. Brown, "Role of the heat shock transcription factor, Hsfl, in a major fungal pathogen that is obligately associated with warm-blooded animals," Molecular Microbiology, vol. 74, no. 4, pp. 844-861, 2009.

[43] H. Sakurai and A. Ota, "Regulation of chaperone gene expression by heat shock transcription factor in Saccharomyces cerevisiae: importance in normal cell growth, stress resistance, and longevity," FEBS Letters, vol. 585, no. 17, pp. 2744-2748, 2011.

[44] S. Nicholls, D. M. MacCallum, F. A. R. Kaffarnik, L. Selway, S. C. Peck, and A. J. P. Brown, "Activation of the heat shock transcription factor Hsfl is essential for the full virulence of the fungal pathogen Candida albicans," Fungal Genetics and Biology, vol. 48, no. 3, pp. 297-305, 2011.

[45] J. Zou, Y. Guo, T. Guettouche, D. F. Smith, and R. Voellmy, "Repression of heat shock transcription factor HSF1 activation by HSP90 (HSP90 complex) that forms a stress-sensitive complex with HSF1," Cell, vol. 94, no. 4, pp. 471-480, 1998.

[46] E. A. Cralg and C. A. Gross, "Is hsp70 the cellular thermometer?" Trends in Biochemical Sciences, vol. 16, no. 1, pp. 135-140, 1991.

[47] J. J. Heinisch, A. Lorberg, H.-P. Schmitz, and J. J. Jacoby, “The protein kinase C-mediated MAP kinase pathway involved in the maintenance of cellular integrity in Saccharomyces cerevisiae," Molecular Microbiology, vol. 32, no. 4, pp. 671-680, 1999.

[48] S. H. Millson, A. W. Truman, V. King, C. Prodromou, L. H. Pearl, and P. W. Piper, "A two-hybrid screen of the yeast proteome for Hsp90 interactors uncovers a novel Hsp90 chaperone requirement in the activity of a stress-activated mitogenactivated protein kinase, Slt2p (Mpklp)," Eukaryotic Cell, vol. 4, no. 5, pp. 849-860, 2005.

[49] S. Welker, B. Rudolph, E. Frenzel et al., "Hsp12 is an intrinsically unstructured stress protein that folds upon membrane association and modulates membrane function," Molecular Cell, vol. 39, no. 4, pp. 507-520, 2010.

[50] R. S. Shapiro and L. E. Cowen, "Uncovering cellular circuitry controlling temperature-dependent fungal morphogenesis," Virulence, vol. 3, no. 4, pp. 400-404, 2012.

[51] M. D. Leach, E. Klipp, L. E. Cowen, and A. J. P. Brown, "Fungal Hsp90: a biological transistor that tunes cellular outputs to thermal inputs," Nature Reviews Microbiology, vol. 10, no. 10, pp. 693-704, 2012.

[52] D. O. Inglis and G. Sherlock, "Ras signaling gets fine-tuned: regulation of multiple pathogenic traits of Candida albicans," Eukaryotic Cell, vol. 12, no. 10, pp. 1316-1325, 2013.

[53] M.-S. Fu, L. De Sordi, and F. A. Mühlschlegel, "Functional characterization of the small heat shock protein Hsp12p from Candida albicans," PLoS ONE, vol. 7, no. 8, Article ID e42894, 2012.

[54] S. L. Lafayette, C. Collins, A. K. Zaas et al., "PKC signaling regulates drug resistance of the fungal pathogen Candida albicans 
via circuitry comprised of mkcl, calcineurin, and hsp90," PLoS Pathogens, vol. 6, no. 8, Article ID e1001069, 2010.

[55] S. Krishnamurthy, V. Gupta, R. Prasad, S. L. Panwar, and R. Prasad, "Expression of CDR1, a multidrug resistance gene of Candida albicans: transcriptional activation by heat shock, drugs and human steroid hormones," FEMS Microbiology Letters, vol. 160, no. 2, pp. 191-197, 1998.

[56] K. Clemons, J. Shankar, and D. Stevens, "Mycologic endocrinology," in Microbial Endocrinology, M. Lyte and P. P. E. Freestone, Eds., pp. 269-290, Springer New York, 2010.

[57] M. E. Feder and G. E. Hofmann, "Heat-shock proteins, molecular chaperones, and the stress response: evolutionary and ecological physiology," Annual Review of Physiology, vol. 61, no. 1, pp. 243-282, 1999.

[58] T. Mahmood, W. Safdar, B. H. Abbasi, and S. M. S. Naqvi, "An overview on the small heat shock proteins," African Journal of Biotechnology, vol. 9, no. 7, pp. 927-939, 2010.

[59] R. M. Ricke and A.-K. Bielinsky, "A conserved Hsp10-like domain in Mcm10 is required to stabilize the catalytic subunit of DNA polymerase- $\alpha$ in budding yeast," The Journal of Biological Chemistry, vol. 281, no. 27, pp. 18414-18425, 2006.

[60] J. Höfeld, Y. Minami, and F.-U. Hartl, "Hip, a novel cochaperone involved in the eukaryotic hsc70/hsp40 reaction cycle," Cell, vol. 83, no. 4, pp. 589-598, 1995.

[61] M.-S. Fu, L. de Sordi, and F. A. Mühlschlegel, "Functional characterization of the small heat shock protein Hsp12p from Candida albicans," PLoS ONE, vol. 7, no. 8, Article ID e42894, 2012.

[62] F. L. Mayer, D. Wilson, I. D. Jacobsen et al., "Small but crucial: the novel small heat shock protein Hsp21 mediates stress adaptation and virulence in Candida albicans," PLoS ONE, vol. 7, no. 6, Article ID e38584, 2012.

[63] M.-A. Lopez-Matas, P. Nuñez, A. Soto et al., "Protein cryoprotective activity of a cytosolic small heat shock protein that accumulates constitutively in chestnut stems and is upregulated by low and high temperatures," Plant Physiology, vol. 134, no. 4, pp. 1708-1717, 2004.

[64] J. Burnie and R. Matthews, “Therapeutic composition," Google Patents, 2006.

[65] H. de Nobel, L. Lawrie, S. Brul et al., "Parallel and comparative analysis of the proteome and transcriptome of sorbic acidstressed Saccharomyces cerevisiae," Yeast, vol. 18, no. 15, pp. 14131428, 2001.

[66] F. U. Hartl and M. Hayer-Hartl, "Molecular chaperones in the cytosol: from nascent chain to folded protein," Science, vol. 295, no. 5561, pp. 1852-1858, 2002.

[67] C.-Y. Fan, S. Lee, and D. M. Cyr, "Mechanisms for regulation of Hsp70 function by Hsp40," Cell Stress \& Chaperones, vol. 8, no. 4, pp. 309-316, 2003.

[68] M. Haslbeck, N. Braun, T. Stromer et al., "Hsp42 is the general small heat shock protein in the cytosol of Saccharomyces cerevisiae," The EMBO Journal, vol. 23, no. 3, pp. 638-649, 2004.

[69] P. M. B. Fernandes, "How does yeast respond to pressure?" Brazilian Journal of Medical and Biological Research, vol. 38, no. 8, pp. 1239-1245, 2005.

[70] M.-F. Tsan and B. Gao, "Heat shock protein and innate immunity," Cellular \& Molecular Immunology, vol. 1, no. 4, pp. 274279, 2004.

[71] F. Cappello, M. Bellafiore, A. Palma et al., "60KDa chaperonin (HSP60) is over-expressed during colorectal carcinogenesis," European Journal of Histochemistry, vol. 47, no. 2, pp. 105-110, 2009.
[72] M. D. Leach, S. Budge, L. Walker, C. Munro, L. E. Cowen, and A. J. P. Brown, "Hsp90 orchestrates transcriptional regulation by Hsfl and cell wall remodelling by MAPK signalling during thermal adaptation in a pathogenic yeast," PLoS Pathogens, vol. 8, no. 12, Article ID e1003069, 2012.

[73] R. P. Hirt, B. Healy, C. R. Vossbrinck, E. U. Canning, and T. M. Embley, "A mitochondrial Hsp70 orthologue in Vairimorpha necatrix: molecular evidence that microsporidia once contained mitochondria," Current Biology, vol. 7, no. 12, pp. 995-998, 1997.

[74] J.-F. Louvion, T. Abbas-Terki, and D. Picard, "Hsp90 is required for pheromone signaling in yeast," Molecular Biology of the Cell, vol. 9, no. 11, pp. 3071-3083, 1998.

[75] D. P. Easton, Y. Kaneko, and J. R. Subjeck, "The Hsp110 and Grp170 stress proteins: newly recognized relatives of the Hsp70s," Cell Stress \& Chaperones, vol. 5, no. 4, pp. 276-290, 2000.

[76] N. Plesofsky-Vig and R. Brambl, "Characterization of an 88$\mathrm{kDa}$ heat shock protein of Neurospora crassa that interacts with Hsp30," The Journal of Biological Chemistry, vol. 273, no. 18, pp. 11335-11341, 1998.

[77] P. K. Sorger, "Heat shock factor and the heat shock response," Cell, vol. 65, no. 3, pp. 363-366, 1991.

[78] D. R. Boreham and R. E. J. Mitchel, "Regulation of heat and radiation stress responses in yeast by hsp-104," Radiation Research, vol. 137, no. 2, pp. 190-195, 1994.

[79] A. S. Borchsenius, R. D. Wegrzyn, G. P. Newnam, S. G. IngeVechtomov, and Y. O. Chernoff, "Yeast prion protein derivative defective in aggregate shearing and production of new 'seeds," The EMBO Journal, vol. 20, no. 23, pp. 6683-6691, 2001.

[80] J. J. Rautio, M. Bailey, T. Kivioja, H. Söderlund, M. Penttilä, and M. Saloheimo, "Physiological evaluation of the filamentous fungus Trichoderma reesei in production processes by marker gene expression analysis," BMC Biotechnology, vol. 7, no. 1, article 28, 2007.

[81] H. Raviol, H. Sadlish, F. Rodriguez, M. P. Mayer, and B. Bukau, "Chaperone network in the yeast cytosol: Hspl10 is revealed as an Hsp70 nucleotide exchange factor," The EMBO Journal, vol. 25, no. 11, pp. 2510-2518, 2006.

[82] J. H. Kim, T. R. Alderson, R. O. Frederick, and J. L. Markley, "Nucleotide-dependent interactions within a specialized Hsp70/Hsp40 complex involved in Fe-S cluster biogenesis," Journal of the American Chemical Society, vol. 136, no. 33, pp. 11586-11589, 2014.

[83] B. Jung, S. Kim, and J. Lee, "Microcyle conidiation in filamentous fungi," Mycobiology, vol. 42, no. 1, pp. 1-5, 2014.

[84] W. J. Steinbach, K. A. Marr, E. J. Anaissie et al., "Clinical epidemiology of 960 patients with invasive aspergillosis from the PATH Alliance registry," Journal of Infection, vol. 65, no. 5, pp. 453-464, 2012.

[85] F. Lamoth, P. R. Juvvadi, and W. J. Steinbach, "Heat shock protein 90 (Hsp90): a novel antifungal target against Aspergillus fumigatus," Critical Reviews in Microbiology, pp. 1-12, 2014.

[86] F. Lamoth, P. R. Juvvadi, C. Gehrke, Y. G. Asfaw, and W. J. Steinbach, "Transcriptional activation of heat shock protein 90 mediated via a proximal promoter region as trigger of caspofungin resistance in Aspergillus fumigatus," Journal of Infectious Diseases, vol. 209, no. 3, pp. 473-481, 2014.

[87] A. J. McClellan, Y. Xia, A. M. Deutschbauer, R. W. Davis, M. Gerstein, and J. Frydman, "Diverse cellular functions of the Hsp90 molecular chaperone uncovered using systems approaches," Cell, vol. 131, no. 1, pp. 121-135, 2007. 
[88] P. M. Ouimet and M. Kapoor, "Nucleotide binding and hydrolysis properties of Neurospora crassa cytosolic molecular chaperones, Hsp70 and Hsp80, heat-inducible members of the eukaryotic stress-70 and stress-90 families," Biochemistry and Cell Biology, vol. 77, no. 2, pp. 89-99, 1999.

[89] T. L. Girvitz, P. M. Ouimet, and M. Kapoor, "Heat shock protein 80 of Neurospora crassa: sequence analysis of the gene and expression during the asexual phase," Canadian Journal of Microbiology, vol. 46, no. 11, pp. 981-991, 2000.

[90] F. Fracella, C. Scholle, A. Kallies, T. Häfker, T. Schröder, and L. Rensing, "Differential HSC70 expression during asexual development of Neurospora crassa," Microbiology, vol. 143, no. 11, pp. 3615-3624, 1997.

[91] T. Häfker, D. Techel, G. Steier, and L. Rensing, "Differential expression of glucose-regulated (grp78) and heat-shockinducible (hsp70) genes during asexual development of Neurospora crassa," Microbiology, vol. 144, no. 1, pp. 37-43, 1998.

[92] A. Brand, "Hyphal growth in human fungal pathogens and its role in virulence," International Journal of Microbiology, vol. 2012, Article ID 517529, 11 pages, 2012.

[93] J. Shankar, T. D. Wu, K. V. Clemons, J. P. Monteiro, L. F. Mirels, and D. A. Stevens, "Influence of $17 \beta$-estradiol on gene expression of Paracoccidioides during mycelia-to-yeast transition," PLoS ONE, vol. 6, no. 12, Article ID e28402, 2011.

[94] J. Shankar, A. Restrepo, K. V. Clemons, and D. A. Stevens, "Hormones and the resistance of women to paracoccidioidomycosis," Clinical Microbiology Reviews, vol. 24, no. 2, pp. 296-313, 2011.

[95] J. P. Monteiro, K. V. Clemons, L. F. Mirels et al., "Genomic DNA microarray comparison of gene expression patterns in Paracoccidioides brasiliensis mycelia and yeasts in vitro," Microbiology, vol. 155, no. 8, pp. 2795-2808, 2009.

[96] A. M. Nicola, R. V. Andrade, A. S. Dantas et al., "The stress responsive and morphologically regulated hsp90 gene from Paracoccidioides brasiliensis is essential to cell viability," $B M C$ Microbiology, vol. 8, no. 1, article 158, 2008.

[97] T. G. F. Matos, F. V. Morais, and C. B. L. Campos, "Hsp90 regulates Paracoccidioides brasiliensis proliferation and ROS levels under thermal stress and cooperates with calcineurin to control yeast to mycelium dimorphism," Medical Mycology, vol. 51, no. 4, pp. 413-421, 2013.

[98] D. A. Cunha, R. M. Zancopé-Oliveira, M. S. S. Felipe, S. M. Salem-Izacc, G. S. Deepe Jr., and C. M. A. Soares, "Heterologous expression, purification, and immunological reactivity of a recombinant HSP60 from Paracoccidioides brasiliensis," Clinical and Diagnostic Laboratory Immunology, vol. 9, no. 2, pp. 374$377,2002$.

[99] M. S. S. Felipe, R. V. Andrade, F. B. M. Arraes et al., "Transcriptional profiles of the human pathogenic fungus Paracoccidioides brasiliensis in mycelium and yeast cells," Journal of Biological Chemistry, vol. 280, no. 26, pp. 24706-24714, 2005.

[100] M. S. S. Felipe, F. A. G. Torres, A. Q. Maranhão et al., "Functional genome of the human pathogenic fungus Paracoccidioides brasiliensis," FEMS Immunology \& Medical Microbiology, vol. 45, no. 3, pp. 369-381, 2005.

[101] S. Hohmann and W. H. Mager, Yeast Stress Responses, Springer Science \& Business Media, New York, NY, USA, 2003.

[102] C. Moraitis and B. P. G. Curran, "Reactive oxygen species may influence the heat shock response and stress tolerance in the yeast Saccharomyces cerevisiae," Yeast, vol. 21, no. 4, pp. 313-323, 2004.
[103] K. V. Clemons, D. Feldman, and D. A. Stevens, "Influence of oestradiol on protein expression and methionine utilization during morphogenesis of Paracoccidioides brasiliensis," Journal of General Microbiology, vol. 135, no. 6, pp. 1607-1617, 1989.

[104] J. Perlman and J. F. Feldman, "Cycloheximide and heat shock induce new polypeptide synthesis in Neurospora crassa," Molecular and Cellular Biology, vol. 2, no. 10, pp. 1167-1173, 1982.

[105] N. Plesofsky-Vig and R. Brambl, "Heat shock response of Neurospora crassa: protein synthesis and induced thermotolerance," Journal of Bacteriology, vol. 162, no. 3, pp. 1083-1091, 1985.

[106] H. V. Colot, G. Park, G. E. Turner et al., "A high-throughput gene knockout procedure for Neurospora reveals functions for multiple transcription factors," Proceedings of the National Academy of Sciences of the United States of America, vol. 103, no. 27, pp. 10352-10357, 2006.

[107] S. K. Upadhyay, J. Shankar, Y. Singh, S. F. Basir, T. Madan, and P. U. Sarma, "Expressed sequence tags of Aspergillus fumigatus: extension of catalogue and their evaluation as putative drug targets and/or diagnostic markers," Indian Journal of Clinical Biochemistry, vol. 24, no. 2, pp. 131-136, 2009.

[108] L. A. Sonna, L. Hawkins, M. E. Lissauer et al., "Core temperature correlates with expression of selected stress and immunomodulatory genes in febrile patients with sepsis and noninfectious SIRS," Cell Stress and Chaperones, vol. 15, no. 1, pp. 55-66, 2010.

[109] Y. Sanchez, J. Taulien, K. A. Borkovich, and S. Lindquist, "Hsp104 is required for tolerance to many forms of stress," The EMBO Journal, vol. 11, no. 6, pp. 2357-2364, 1992.

[110] Y. Sanchez, D. A. Parsell, J. Taulien, J. L. Vogel, E. A. Craig, and S. Lindquist, "Genetic evidence for a functional relationship between Hsp104 and Hsp70," Journal of Bacteriology, vol. 175, no. 20, pp. 6484-6491, 1993.

[111] A. Pacheco, C. Pereira, M. J. Almeida, and M. J. Sousa, "Small heat-shock protein Hsp12 contributes to yeast tolerance to freezing stress," Microbiology, vol. 155, no. 6, pp. 2021-2028, 2009.

[112] M. Petitjean, M. Teste, J. M. François, and J. Parrou, "Yeast tolerance to various stresses relies on the trehalose-6P synthase (Tps1) protein, not on trehalose," The Journal of Biological Chemistry, vol. 290, no. 26, pp. 16177-16190, 2015.

[113] T. Miura, H. Minegishi, R. Usami, and F. Abe, "Systematic analysis of HSP gene expression and effects on cell growth and survival at high hydrostatic pressure in Saccharomyces cerevisiae," Extremophiles, vol. 10, no. 4, pp. 279-284, 2006.

[114] Y. Dubaquié, R. Looser, and S. Rospert, "Significance of chaperonin 10-mediated inhibition of ATP hydrolysis by chaperonin 60," Proceedings of the National Academy of Sciences of the United States of America, vol. 94, no. 17, pp. 9011-9016, 1997.

[115] Y. Murata, T. Homma, E. Kitagawa et al., "Genome-wide expression analysis of yeast response during exposure to $4^{\circ} \mathrm{C}$," Extremophiles, vol. 10, no. 2, pp. 117-128, 2006.

[116] O. Kandror, N. Bretschneider, E. Kreydin, D. Cavalieri, and A. L. Goldberg, "Yeast adapt to near-freezing temperatures by STRE/Msn2,4-dependent induction of trehalose synthesis and certain molecular chaperones," Molecular Cell, vol. 13, no. 6, pp. 771-781, 2004.

[117] K. Sales, W. Brandt, E. Rumbak, and G. Lindsey, “The LEA-like protein HSP 12 in Saccharomyces cerevisiae has a plasma membrane location and protects membranes against desiccation and ethanol-induced stress," Biochimica et Biophysica Acta (BBA)— Biomembranes, vol. 1463, no. 2, pp. 267-278, 2000.

[118] J. S. Freitas, E. M. Silva, J. Leal et al., "Transcription of the Hsp30, Hsp70, and Hsp90 heat shock protein genes is modulated by 
the PalA protein in response to acid $\mathrm{pH}$-sensing in the fungus Aspergillus nidulans," Cell Stress and Chaperones, vol. 16, no. 5, pp. 565-572, 2011.

[119] F. M. Squina, J. Leal, V. T. F. Cipriano, N. M. Martinez-Rossi, and A. Rossi, "Transcription of the Neurospora crassa $70-\mathrm{kDa}$ class heat shock protein genes is modulated in response to extracellular pH changes," Cell Stress and Chaperones, vol. 15, no. 2, pp. 225-231, 2010.

[120] E. M. Silva, J. S. Freitas, D. E. Gras et al., "Identification of genes differentially expressed in a strain of the mold Aspergillus nidulans carrying a loss-of-function mutation in the palA gene," Canadian Journal of Microbiology, vol. 54, no. 10, pp. 803-811, 2008.

[121] D. Canadell, J. García-Martínez, P. Alepuz, J. E. Pérez-Ortín, and J. Ariño, "Impact of high $\mathrm{pH}$ stress on yeast gene expression: a comprehensive analysis of mRNA turnover during stress responses," Biochimica et Biophysica Acta, vol. 1849, no. 6, pp. 653-664, 2015.

[122] P. M. B. Fernandes, T. Domitrovic, C. M. Kao, and E. Kurtenbach, "Genomic expression pattern in Saccharomyces cerevisiae cells in response to high hydrostatic pressure," FEBS Letters, vol. 556, no. 1-3, pp. 153-160, 2004.

[123] P. Lee, B.-R. Cho, H.-S. Joo, and J.-S. Hahn, "Yeast Yak1 kinase, a bridge between PKA and stress-responsive transcription factors, Hsf1 and Msn2/Msn4," Molecular Microbiology, vol. 70, no. 4, pp. 882-895, 2008.

[124] P. W. Piper, C. Ortiz-Calderon, C. Holyoak, P. Coote, and M. Cole, "Hsp30, the integral plasma membrane heat shock protein of Saccharomyces cerevisiae, is a stress-inducible regulator of plasma membrane $\mathrm{H}^{+}$-ATPase," Cell Stress and Chaperones, vol. 2, no. 1, pp. 12-24, 1997.

[125] S. A. Leonhardt, K. Fearon, P. N. Danese, and T. L. Mason, "HSP78 encodes a yeast mitochondrial heat shock protein in the Clp family of ATP-dependent proteases," Molecular and Cellular Biology, vol. 13, no. 10, pp. 6304-6313, 1993.

[126] H. Iwahashi, K. Obuchi, S. Fujii, and Y. Komatsu, "Barotolerance is dependent on both trehalose and heat shock protein 104 but is essentially different from thermotolerance in Saccharomyces cerevisiae," Letters in Applied Microbiology, vol. 25, no. 1, pp. 4347, 1997.

[127] K. Tamura, M. Miyashita, and H. Iwahashi, "Stress tolerance of pressure-shocked Saccharomyces cerevisiae," Biotechnology Letters, vol. 20, no. 12, pp. 1167-1169, 1998.

[128] L. E. Cowen and S. Lindquist, "Hsp90 potentiates the rapid evolution of new traits: drug resistance in diverse fungi," Science, vol. 309, no. 5744, pp. 2185-2189, 2005.

[129] L. E. Cowen, S. D. Singh, J. R. Köhler et al., "Harnessing Hsp90 function as a powerful, broadly effective therapeutic strategy for fungal infectious disease," Proceedings of the National Academy of Sciences of the United States of America, vol. 106, no. 8, pp. 2818-2823, 2009.

[130] P. R. Juvvadi, F. Lamoth, and W. J. Steinbach, "Calcineurin as a multifunctional regulator: unraveling novel functions in fungal stress responses, hyphal growth, drug resistance, and pathogenesis," Fungal Biology Reviews, vol. 28, no. 2, pp. 56-69, 2014.

[131] P. Gautam, J. Shankar, T. Madan et al., "Proteomic and transcriptomic analysis of Aspergillus fumigatus on exposure to amphotericin B," Antimicrobial Agents and Chemotherapy, vol. 52, no. 12, pp. 4220-4227, 2008.
[132] E. Kummer, Y. Oguchi, F. Seyffer, B. Bukau, and A. Mogk, "Mechanism of Hsp104/ClpB inhibition by prion curing Guanidinium hydrochloride," FEBS Letters, vol. 587, no. 6, pp. 810-817, 2013.

[133] T. Majumder, M. Liu, V. Chen et al., "Killed Saccharomyces cerevisiae protects against lethal challenge of Cryptococcus grubii," Mycopathologia, vol. 178, no. 3-4, pp. 189-195, 2014.

[134] P. S. Coelho, H. Im, K. V. Clemons, M. P. Snyder, and D. A. Stevens, "Evaluating common humoral responses against fungal infections with yeast protein microarrays," Journal of Proteome Research, vol. 14, no. 9, pp. 3924-3931, 2015. 

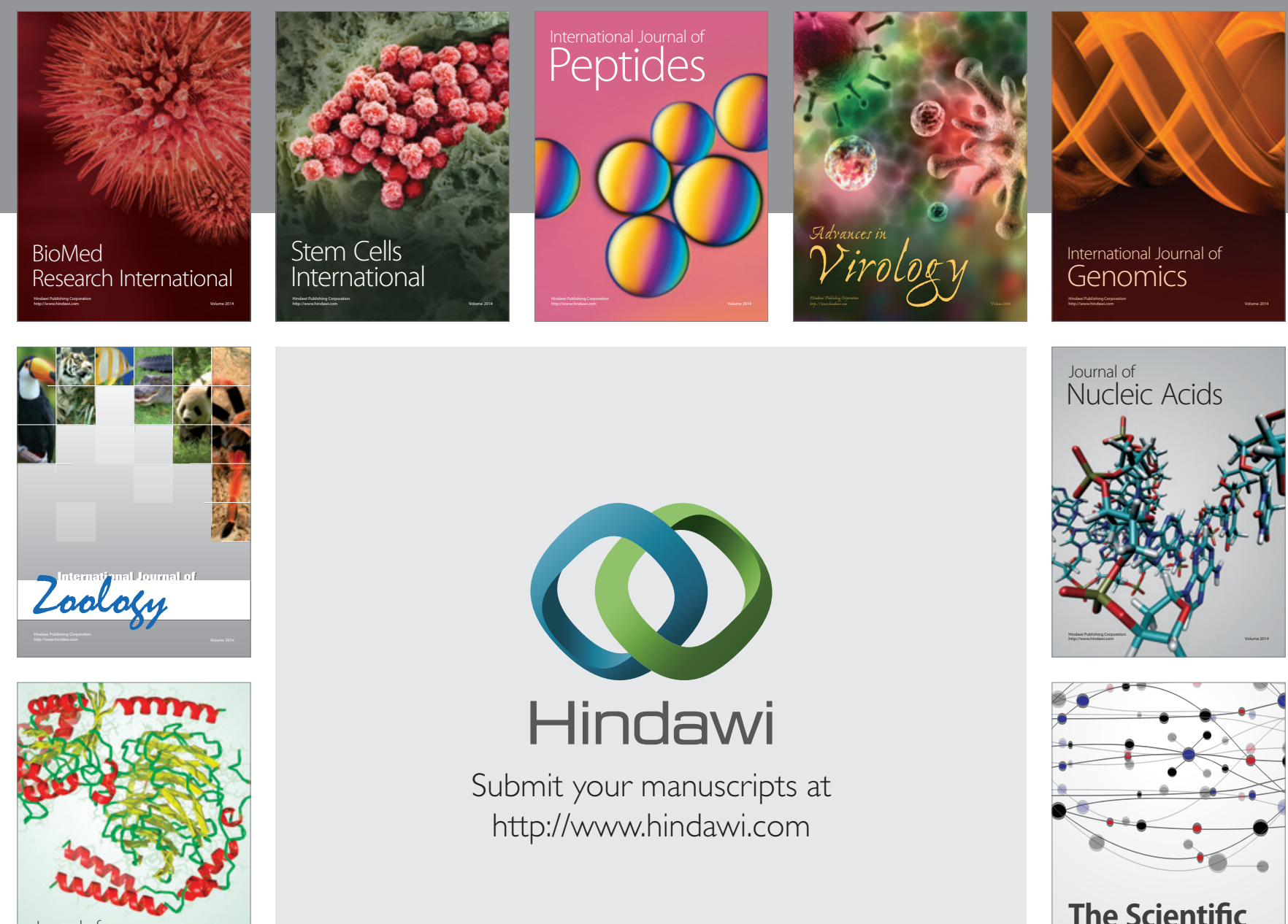

Submit your manuscripts at

http://www.hindawi.com

Journal of
Signal Transduction
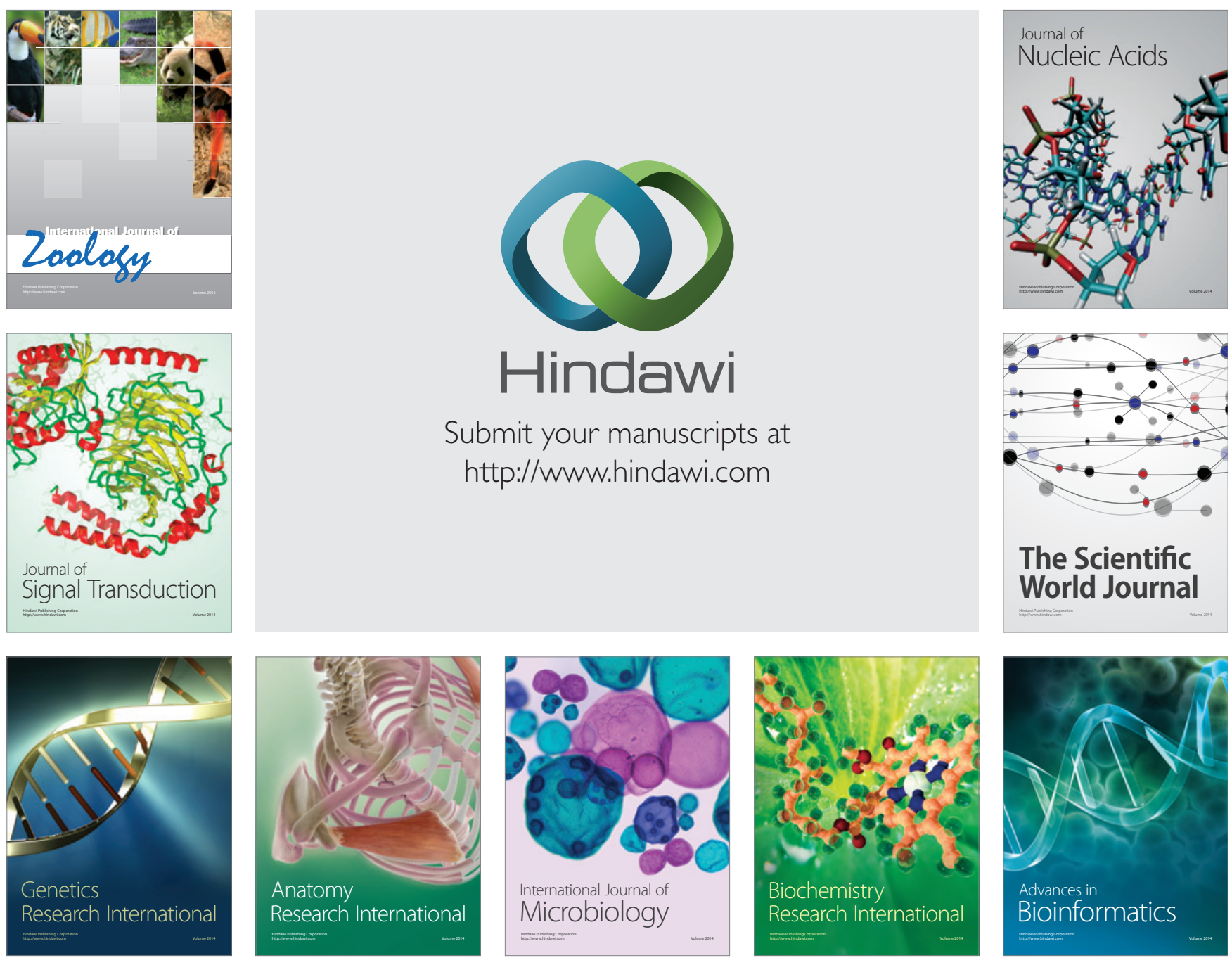

The Scientific World Journal
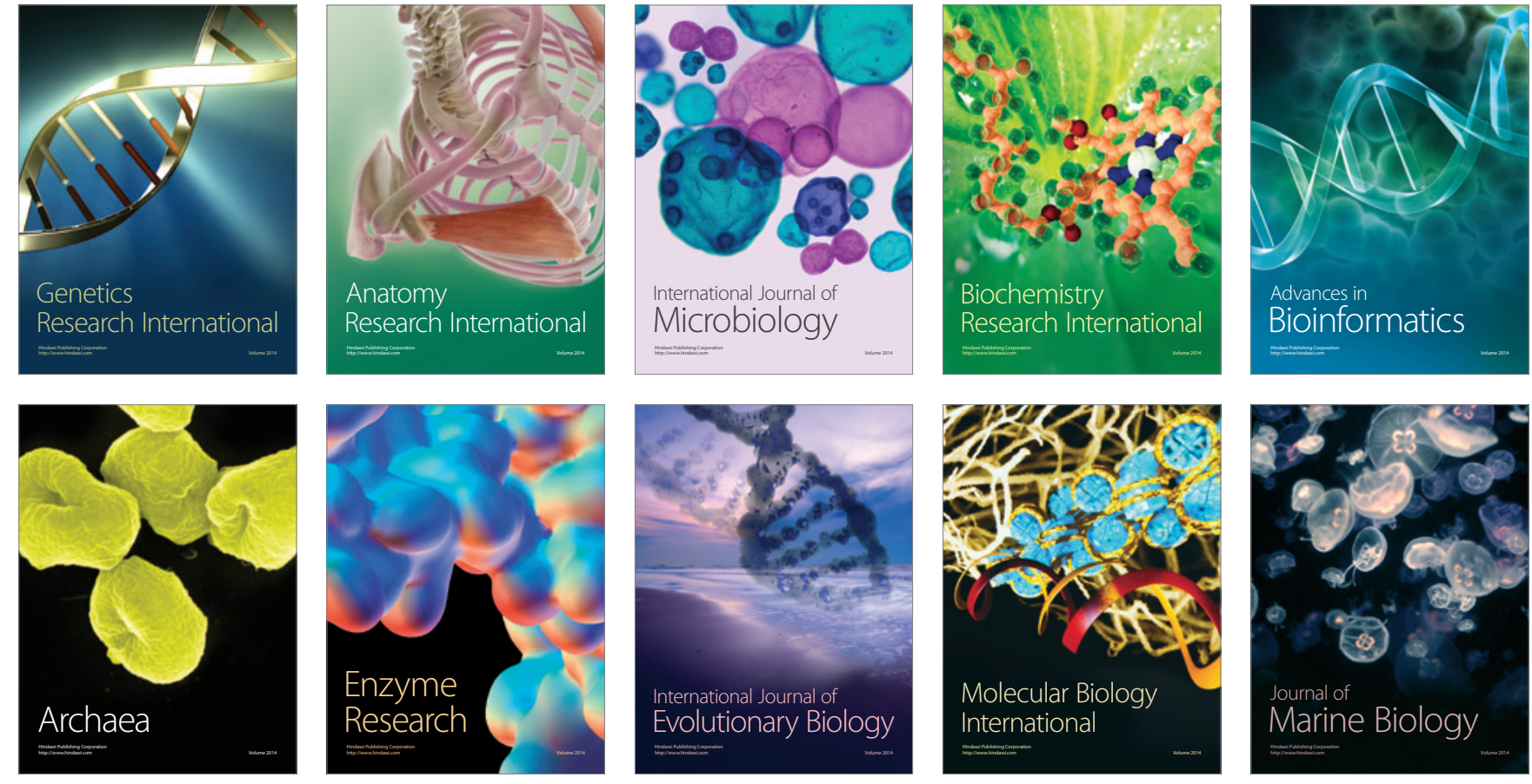